\title{
DEVELOPMENT OF A COST EFFECTIVE MEDIUM FOR PRODUCTION OF BACILLUS THURINGIENSIS BIOINSECTICIDE USING FOOD BARLEY
}

\author{
Mohammad Shojaaddini ${ }^{1}$, Saeid Moharramipour ${ }^{*}$, Mahvash Khodabandeh ${ }^{2}$, Ali Asghar Talebi ${ }^{1}$
}

${ }^{1}$ Department of Entomology, Faculty of Agriculture, Tarbiat Modares University, Tehran, P.O. Box 14115-336, Iran

${ }^{2}$ National Institute of Genetic Engineering and Biotechnology (NIGEB), Tehran, Iran

Received: March 1, 2009

Accepted: August 6, 2009

\begin{abstract}
Genetically manipulated food barley, Hordeum vulgare L. var. valfajr, was compared to commercial-grade starch as carbon sources in groundnut and soybean based media for supporting growth, sporulation and delta-endotoxin production by Bacillus thuringiensis Berliner B. thuringiensis kurstaki HD-1 and a promising newly isolated B. thuringiensis strain (referred to as BTA) were used. $\mathrm{MgCl}_{2}, \mathrm{CaCl}_{2^{\prime}}$ and $\mathrm{MnCl}_{2}$ were used as trace-elements. Culture media were compared in shaken flasks and then in 51 Fermentors. Biomass, delta-endotoxin levels and the number of spores as colony forming units (CFU) were evaluated. For each of the two strains, biomass and delta-endotoxin synthesis were not significantly different in soybean-based media after substitution starch by barley flour. There were significant differences between the two strains with respect to biomass and toxin production. Evaluated costs of media preparation showed that food barley is an economical alternative to commercial-grade starch in the production of BTA bioinsecticide.
\end{abstract}

Key words: food barley, culture media, Bacillus thuringiensis, bioinsecticide

\section{INTRODUCTION}

Over the past century, the insecticidal bacterium Bacillus thuringiensis Berliner proved to be an interesting minor pathogen of caterpillars, thus beinig an environmentally safe insecticide for controlling pests of major crops and vectors of human diseases. B. thuringiensis bioinsecticides are composed of mixture of spores and crystals harvested from production media. Spores and crystals of $B$. thuringiensis are readily produced by aerated liquid fermentation. They are easily harvested and, when properly formulated, have a long shelf life (Zouari et al. 2002; Prabakaran and Balaraman 2006; Jing-Wen et al. 2007). At present the cost of $B$. thuringiensis production using existing fermentation technology is high because of a high cost of the production medium. Less expensive media for culturing of $B$. thuringiensis will facilitate production of biopesticides by utilization of cost effective alternative agricultural products. Fermentation studies showed that large-scale production of $B$. thuringiensis is possible at a relatively competitive cost. Although progressive development of $B$. thuringiensis as a bioinsecticide is evident, key solutions may lead to further commercialization and development of this bacterium as an environmentally safe insecticide. A high cost of B. thuringiensis products is due to production being mostly located in developed countries where production costs are higher, and also expenses paid in transportation to other countries. Thus, local production could significantly reduce costs of pest control and help with the development and improvement of local fermentation industries, besides the utilization of more economic agricultural products.

In order to reduce production costs, many raw materials and cheap byproducts were tested and used. Media containing fishmeal, and corn-steep liquor for production of B. thuringiensis were reported (Saalma 1983; Kumar et al. 2000). Media containing molasses, corn extract, and mineral salts (Dregval et al. 1999), corn steep liquor, glucose, and mineral salts (Luna 2004), glucose, corn extract, sodium humate, and mineral salts (Dregval et al. 2002), or potato, common sugar, and Bengal gram (Cicer arietinum L.) (Poopathi and Kumar 2003) were all used for growth and production of $B$. thuringiensis. Powders of edible leguminous seeds and mung bean Vigna radiata (L.) R. Wilczek were used as major sources of protein together with different combinations of soluble starch and/or sugarcane molasses as major carbohydrate sources for the production of delta-endotoxin (Mummigatti and Raghunathan 1990). Similarly, soybean four, groundnut cake powder and, wheat bran extract (Triticum aestivum L.) were separately used in large-scale production of $B$. thuringiensis bioinsecticide (Prabakaran and Balaraman 2006).

Barley (Hordeum vulgare L.) grain is used in malt production and as a source of food for humans and animals. Hull-less or naked barley is a genetically improved variety that allows easier removal of a hull. It was investigated as whole grain for several potential new applications (Helm and Francisco 2004). In Iran, barley is cultivated on 1.83 million hectares of land under diverse and vari- 
able agro-climatic conditions. It ranks second among the cultivated crops in terms of hectares and is produced to approximately three million tones per year. Barley is primarily produced and used as animal feed in Iran, it is also consumed as malt, food in the form of "barley soup" and ma-ol shaer (non-alcoholic beer) (Grando and Macpherson 2008). Food barley can play an important role in the sustainability of agricultural production systems in Iran. The goal of the present work was to develop fermentation media using food barley rather than commercialgrade starch for low-cost production of bioinsecticide by a newly isolated $B$. thuringiensis strain with suitable characteristics for the control of pest caterpillars.

\section{MATERIALS AND METHODS}

\section{B. thuringiensis strain}

A new B. thuringiensis aizawai strain, having certain promising characteristics in controlling pest caterpillars (data not published) was used. It was recently isolated by Shojaaddini from a wild population of Indian meal moth, Plodia interpunctella Hübner. B. thuringiensis kurstaki HD-1, kindly provided by Dr. J-F Cherles (Pasteur Institute, Paris, France), was used as reference strain. The bacterial strains were grown on nutrient agar medium (Merck KGaA, Darmstadt, Germany) composed of $5 \mathrm{~g} / \mathrm{l}$ meat peptone, $3 \mathrm{~g} / 1$ meat extract and, $12 \mathrm{~g} / \mathrm{l}$ agar and then stored at $4^{\circ} \mathrm{C}$.

\section{Media preparation}

Hull-less grains of food barley (Hordeum vulgare var. valfajr, facultative type) and commercial soybean cake (Glycine max), containing 46\% proteins, were obtained from Sobhan food-industry, Tehran, Iran. Commercialgrade starch, (Nemooneh Co., Karaj, Tehran) and groundnut (Arachis hypogea L.) were purchased from the Iranian market. All materials were finely grinded and all media were prepared at $2.5 \%(\mathrm{w} / \mathrm{v})$. Medium " $\mathrm{A}$ " consisted of soybean flour and starch, " $\mathrm{B}$ " consisted of soybean flour and food barley flour, " $\mathrm{C}$ " consisted of groundnut powder and starch and, " $\mathrm{D}$ " consisted of groundnut powder and food barley flour. Ingredients of media " $B$ " and " $C$ " were soaked in distilled water for $1 \mathrm{~h}$. The ingredients of all media were dissolved in distilled water and filtered through a plastic strainer (mesh size $100 \mu \mathrm{m}$ ) to remove all the insoluble solid particles. To each liter of the above media, $10 \mathrm{ml}$ of stock salt solution (20.3 $\mathrm{g} \mathrm{MgCl}_{2^{\prime}} 10.2 \mathrm{~g}$ $\mathrm{CaCl}_{2}$, and $1.0 \mathrm{~g} \mathrm{MnCl}_{2} / 1$ of distilled water) was added, according to the method by Prabakaran and Balaraman (2006). The $\mathrm{pH}$ of the medium was adjusted to 7.0 prior to inoculation.

\section{Bioinsecticide production in shaken flasks}

Inocula were prepared by transferring cells from nutrient agar media into $10 \mathrm{ml}$ of nutrient broth liquid media (Merck KGaA, Darmstadt, Germany) containing 5 g/l meat peptone and $3 \mathrm{~g} / \mathrm{l}$ meat extract. After $12 \mathrm{~h}$ of incubation at $30^{\circ} \mathrm{C}$ in a shaker-incubator at $200 \mathrm{rpm}$, optical densities were determined and equally adjusted for all four different media. Culture broths were then used to inoculate 11 erlenmeyer flasks, containing $250 \mathrm{ml}$ of the above four culture media. These flasks were then incubated for $72 \mathrm{~h}$ at $30^{\circ} \mathrm{C}$ in a shaker-incubator at $200 \mathrm{rpm}$.

\section{Seed culture preparation}

The seed culture was produced using shaken flasks. First-stage seed culture was prepared by inoculating $10 \mathrm{ml}$ of nutrient broth in a test tube with one loop-full of strain and incubating the tube in a shaker-incubator at $30^{\circ} \mathrm{C}, 200 \mathrm{rpm}$ for a period of $10 \mathrm{~h}$. Second-stage seed culture was prepared by transferring $10 \mathrm{ml}$ of first stage seed into $190 \mathrm{ml}$ of the same medium in a 11 erlenmeyer flask and incubating in a shaker-incubator at $30^{\circ} \mathrm{C}$, $200 \mathrm{rpm}$ for a period of $10 \mathrm{~h}$.

\section{Fermentation procedure}

Two media were selected for the purpose of bioinsecticide production in the fermentor. Actively growing second stage seed cultures were used to inoculate the fermentors at $10 \%(\mathrm{v} / \mathrm{v})$ and optical density (OD) of 0.4 . The fermentor used in this study (Tryton, Pierre Guerin, France) had a working volume of 51 and controlled the fermentation variables automatically. The medium (2 1) was sterilized in situ and the fermentation process was then started in batch mode with the following conditions: temperature $30^{\circ} \mathrm{C}$, stirrer speed $250 \mathrm{rpm}, \mathrm{pH}$ controller was connected to $2 \mathrm{~N} \mathrm{NaOH}$ and the $\mathrm{pH}$ was never allowed to drop below 6.8. Moreover, rise in $\mathrm{pH}$ above 7.2 was controlled with $\mathrm{HCl} 20 \%$ (v/v). Dissolved oxygen (DO) was maintained between 20 and $40 \%$ saturation by controlling the air flow that was set at $1 \mathrm{1} / \mathrm{l} / \mathrm{min}$. Silicone at $0.98 \mathrm{~g} / \mathrm{ml}$ (Merck KGaA, Darmstadt, Germany) was used as antifoam agent. Fermentation was terminated after the completion of the spore crystal complex. Samples were withdrawn at $2 \mathrm{~h}$ intervals and used for delta-endotoxin determination. The fermentation was carried out twice for each medium.

\section{Cell mass}

After fermentation was completed, two samples (45 ml) were taken from each fermentor and then centrifuged at $8000 \mathrm{rpm}$ for $15 \mathrm{~min}$. The supernatants were discarded and the cell pellets were lyophilized. Dry weight was calculated and expressed in grams per liter $(\mathrm{g} / \mathrm{l})$.

\section{Spore count}

The two culture samples taken from each fermentor were heat treated at $80^{\circ} \mathrm{C}$ for $15 \mathrm{~min}$, serially diluted, and plated onto NA plates. Plates were then incubated at $37^{\circ} \mathrm{C}$ for $20 \mathrm{~h}$ and the developed $B$. thuringiensis colonies were counted and expressed in CFU (colony forming units) per $\mathrm{ml}$.

\section{Delta-endotoxins determination}

Delta-endotoxin concentration was determined in a solubilized crystal preparation from each culture medium as described by Prabakaran and Balaraman (2006). In summary, $1 \mathrm{ml}$ of culture medium was centrifuged for $10 \mathrm{~min}$ at $10000 \mathrm{~g}$ and the resulting pellet was washed twice with $\mathrm{NaCl}(1 \mathrm{~m} / \mathrm{l})$ and twice with distilled water. The pellet was then suspended in $1 \mathrm{ml}$ of $\mathrm{NaOH}(50 \mathrm{mmol} / \mathrm{l}, \mathrm{pH}$ $12.5)$ in order to solubilize delta-endotoxin crystals. After 
$2 \mathrm{~h}$ of incubation at $37^{\circ} \mathrm{C}$, total proteins in the supernatant was measured by using the Bio-Rad Protein Assay Kit (München, Germany), in accordance with the method by Bradford (1976). The values presented are the averages of the results of two determinations of two separate experiments for each culture condition. The toxin synthesis yield was calculated as the ratio of delta-endotoxin $(\mathrm{mg} / \mathrm{l})$ relative to CFU (spores/l).

\section{Analysis of protein profile}

Purified crystal preparations from each fermentor were incubated with trypsin (Sigma) for $5 \mathrm{~h}$ at $30^{\circ} \mathrm{C}$. Active toxins were solubilized at $100^{\circ} \mathrm{C}$ in sample buffer: Tris- $\mathrm{HCl}(62.5 \mathrm{mM}, \mathrm{pH} 6.8)$, SDS (2\%), glycerol (10\%), mercaptoethanol (5\%) and bromophenol blue $(0.1 \%)$, before being loaded on the gel. SDS-PAGE was performed using the standard discontinuous buffer system of Laemmli (1970) using 10\% polyacrylamide gel to confirm the presence of toxin bands of molecular weight of 57-68 kDa for these two Lepidoptera specific strains.

\section{Statistical analysis}

All data obtained from the determination of cell mass, delta-endotoxin production and CFU counts were the mean of two separate samples for each culture media.
Data were statistically analyzed by SPSS software (Version 9.0.0) using the one-way ANOVA test to compare the means.

\section{RESULTS}

\section{Bioinsecticide production in shaken flask. Comparison} of the two strains

According to the pooled data obtained from all four culture media, biomasses produced by the two strains were significantly different $(F=201.33, p<0.01)$ and HD1 produced 1.5 fold more mean dry weight than the BTA strain $(12.52 \pm 0.22 \mathrm{~g} / \mathrm{l}$ and $8.20 \pm 0.21 \mathrm{~g} / \mathrm{l}$ by HD1 and BTA, respectively). Delta-endotoxin synthesis yield by the two strains, was significantly different $(\mathrm{F}=6.049, \mathrm{p}<0.05)$ and HD1 synthesized approximately 3.7 fold more toxin than BTA. Results of spore count produced by the two strains were significantly different $(F=11.36, p<0.01)$ and the highest mean spore count of $357.18 \times 10^{6} \mathrm{CFU} / \mathrm{ml}$ was observed in the BTA strain that was approximately 4.8 fold higher than for HD1 strain $\left(74.67 \times 10^{6} \mathrm{CFU} / \mathrm{ml}\right)$ (Table 1).

\section{Comparison of four different media}

Each of the two strains, using four different culture media showed no significant difference in producing

Table 1. Production of bioinsecticide by BTA and HD1 strains of B. thuringiensis using four different media in shaken flasks after $72 \mathrm{~h}$

\begin{tabular}{|c|c|c|c|c|}
\hline Strain & Media & $\begin{array}{c}\mathrm{CFU}^{1} \\
{\left[10^{6} / \mathrm{ml}\right]}\end{array}$ & $\begin{array}{c}\text { Toxin synthesis yield }{ }^{2} \\
\text { [mg } / 10^{8} \text { spore] }\end{array}$ & $\begin{array}{c}\text { Dry biomass } \\
{[\mathrm{g} / \mathrm{l}] \pm \mathrm{SE}}\end{array}$ \\
\hline \multirow{5}{*}{ BTA } & $\mathrm{A}$ & $733.400 \pm 33.5$ & $0.1519 \pm 0.012$ & $7.59 \pm 0.04$ \\
\hline & $\mathrm{B}$ & $261.340 \pm 23.7$ & $0.5717 \pm 0.22$ & $7.91 \pm 0.04$ \\
\hline & $\mathrm{C}$ & $250.600 \pm 19.1$ & $0.7222 \pm 0.024$ & $7.95 \pm 0.48$ \\
\hline & $\mathrm{D}$ & $183.340 \pm 23.3$ & $0.6445 \pm 0.040$ & $8.88 \pm 0.36$ \\
\hline & Mean & 357.18 & 0.552 & 8.20 \\
\hline \multirow{5}{*}{ HD1 } & $\mathrm{A}$ & $113.340 \pm 12.6$ & $1.0457 \pm 0.031$ & $13.02 \pm 0.24$ \\
\hline & $\mathrm{B}$ & $78.000 \pm 8.4$ & $1.4695 \pm 0.093$ & $12.15 \pm 0.95$ \\
\hline & $\mathrm{C}$ & $22.730 \pm 2.5$ & $4.5119 \pm 1.653$ & $12.65 \pm 0.26$ \\
\hline & $\mathrm{D}$ & $84.610 \pm 7.7$ & $0.7214 \pm 0.043$ & $12.88 \pm 0.18$ \\
\hline & Mean & 74.67 & 1.937 & 12.52 \\
\hline
\end{tabular}

${ }^{1}$ colony forming units

${ }^{2}$ toxin synthesis yield was calculated as the ratio of delta-endotoxin [mg/l] over CFU [pores/1]

Table 2. Comparative costs for production of one $\mathrm{kg}$ of dry biomass by the BTA strain using four different media

\begin{tabular}{|c|c|c|c|c|c|}
\hline \multirow{2}{*}{ Media } & \multirow{2}{*}{ Media components } & \multirow{2}{*}{$\begin{array}{l}\text { Quantity used in } \\
\text { media }\end{array}$} & \multirow{2}{*}{$\begin{array}{l}\text { Cost of quantity } \\
\text { used [US } \$]^{1}\end{array}$} & \multicolumn{2}{|c|}{$\begin{array}{l}\text { Total cost for production of } 1 \mathrm{~kg} \text { dry } \\
\text { biomass [US \$] }\end{array}$} \\
\hline & & & & shake flask & fermentor \\
\hline \multirow{3}{*}{ Medium A } & soybean & $12.8[\mathrm{~g} / 1]$ & 0.0151 & \multirow{3}{*}{11.18} & \multirow{3}{*}{8.62} \\
\hline & starch & $12.2[\mathrm{~g} / 1]$ & 0.0459 & & \\
\hline & salt solution & $0.315[\mathrm{ml} / \mathrm{l}]$ & 0.024 & & \\
\hline \multirow{3}{*}{ Medium B } & soybean & $12.8[\mathrm{~g} / \mathrm{l}]$ & 0.0151 & \multirow{3}{*}{5.93} & \multirow{3}{*}{6.18} \\
\hline & barley & $12.2[\mathrm{~g} / \mathrm{l}]$ & 0.0078 & & \\
\hline & salt solution & $0.315[\mathrm{ml} / \mathrm{l}]$ & 0.024 & & \\
\hline \multirow{3}{*}{ Medium C } & groundnut & $12.8[\mathrm{~g} / \mathrm{l}]$ & 0.0413 & \multirow{3}{*}{13.98} & \multirow{3}{*}{$\mathrm{Nt}$} \\
\hline & starch & $12.8[\mathrm{~g} / \mathrm{l}]$ & 0.0459 & & \\
\hline & salt solution & $0.315[\mathrm{ml} / \mathrm{l}]$ & 0.024 & & \\
\hline \multirow{3}{*}{ Medium D } & groundnut & $12.8[\mathrm{~g} / \mathrm{l}]$ & 0.0413 & \multirow{3}{*}{8.23} & \multirow{3}{*}{ NT } \\
\hline & barley & $12.2[\mathrm{~g} / 1]$ & 0.0078 & & \\
\hline & salt solution & $0.315[\mathrm{ml} / \mathrm{l}]$ & 0.024 & & \\
\hline
\end{tabular}

${ }^{1}$ all prices were calculated according to the prices of Iran domestic market on January, 2009, NT - not tested 
Table 3. Production of bioinsecticide by BTA and HD1 strains of B. thuringiensis using two different media, in 5L fermentor

\begin{tabular}{|c|c|c|c|c|}
\hline \multirow{2}{*}{ Strain } & Media & $\begin{array}{c}\text { CFU } \\
{\left[10^{6} / \mathrm{ml}\right]}\end{array}$ & $\begin{array}{c}\text { Toxin synthesis yield } \\
{\left[\mathrm{mg} / 10^{8} \text { spore }\right]}\end{array}$ & $\begin{array}{c}\text { Dry biomass } \\
{[\mathrm{g} / \mathrm{l}] \pm \mathrm{SE}}\end{array}$ \\
\hline \multirow{2}{*}{ BTA } & A & $212.01 \pm 12.7$ & $1.51 \pm 0.06$ & $9.85 \pm 0.34$ \\
\cline { 2 - 5 } & B & $181.32 \pm 10.4$ & $1.77 \pm 0.04$ & $7.58 \pm 0.63$ \\
\hline \multirow{2}{*}{ HD1 } & A & $15.60 \pm 1.7$ & $9.39 \pm 0.32$ & $8.67 \pm 0.05$ \\
\cline { 2 - 5 } & B & $31.40 \pm 2.2$ & $9.58 \pm 0.65$ & $10.57 \pm 0.04$ \\
\hline
\end{tabular}

${ }^{1}$ colony forming units; ${ }^{2}$ toxin synthesis yield was calculated as the ratio of delta-endotoxin [mg/l] by CFU [spores/l]

dry biomass (BTA: $\mathrm{F}=0.159, \mathrm{p}=0.922 ; \mathrm{HD} 1: \mathrm{F}=0.01$, $\mathrm{p}=0.970)$. Also using these culture media had no significant effect on delta-endotoxin production by HD1 and BTA strains (BTA: $\mathrm{F}=2.63, \mathrm{p}=0.095$; HD1: 3.54, $\mathrm{p}=$ 0.028). Different spore counts were obtained for four used culture media $(\mathrm{F}=19.4, \mathrm{p}<0.01)$ they were the highest for BTA strain $\left(733.4 \times 10^{6} \mathrm{CFU} / \mathrm{ml}\right)$ in medium $\mathrm{A}$ and the lowest $\left(183.34 \times 10^{6} \mathrm{CFU} / \mathrm{ml}\right)$ in medium D. Similarly, HD1 produced different amounts of spores $(\mathrm{F}=16.6, \mathrm{p}<0.01)$ in different culture media so that the highest spore count was observed in medium $\mathrm{A}\left(113.34 \times 10^{6} \mathrm{CFU} / \mathrm{ml}\right)$ and the lowest in medium C $\left(22.73 \times 10^{6} \mathrm{CFU} / \mathrm{ml}\right)$ (Table 1$)$.

\section{Bioinsecticide production in fermentor Comparison of the two strains}

After bioinsecticide was produced by the two strains in four different media in shaken flasks, the media preparation cost was calculated for each medium and according to a relatively lower cost of production of $1 \mathrm{~kg}$ dry biomass (Table 2), two soybean based media were selected for mass production in the fermentor stage. Pooled data of the two culture media (A and B) showed that biomass in HD1 and BTA strains were not significantly different $(F=0.035, p>0.05)$. Delta-endotoxin synthesis yield was significantly different for the two strains $(F=9.73$, $\mathrm{p}<0.05$ ) on two different culture media (Fig. 1). HD1 showed approximately 5.8 fold higher toxin synthesis yield in average. Spore counts did not show significant difference between strains $(\mathrm{F}=298, \mathrm{p}<0.01)$ and maximum spore count of $212.01 \times 10^{6} \mathrm{CFU} / \mathrm{ml}$ was observed for the BTA strain in medium A (Table 3).

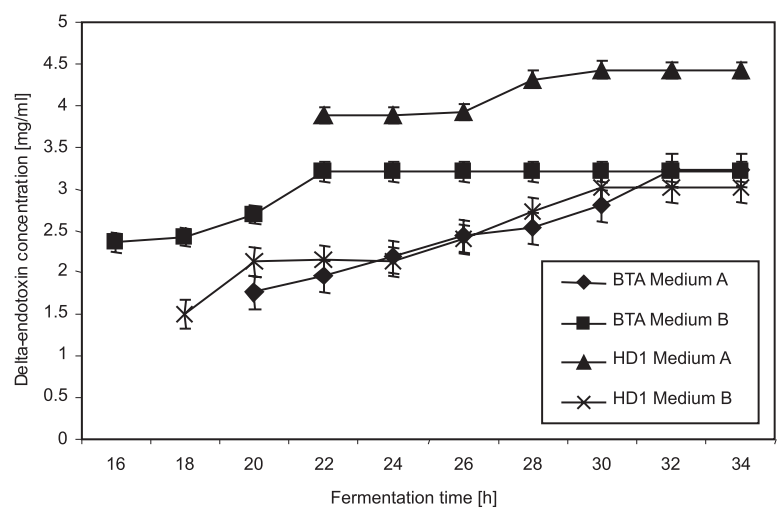

Fig. 1. Delta-endotoxin production by BTA and HD1 strains using two different media in 51 fermentor

\section{Comparison of two different media}

For each of the two strains, biomass produced in different media, delta-endotoxin synthesis yields and also CFU counts were not significantly different $(\mathrm{F}=0.99$, $\mathrm{p}>0.05 ; \mathrm{F}=1.36, \mathrm{p}>0.05 ; \mathrm{F}=0.01, \mathrm{p}>0.05$, respectively).

\section{Analysis of protein profile}

In all four culture media used for bioinsecticide production, both in flasks or fermentors, when starch was substituted by barley, both strains were successful in delta-endotoxin synthesis (Fig. 2) and SDS-PAGE of trypsin-incubated solubilized delta-endotoxins showed toxin bands of about 57-68 kDa in both soybean-based culture media produced by the two strains (Fig. 2).

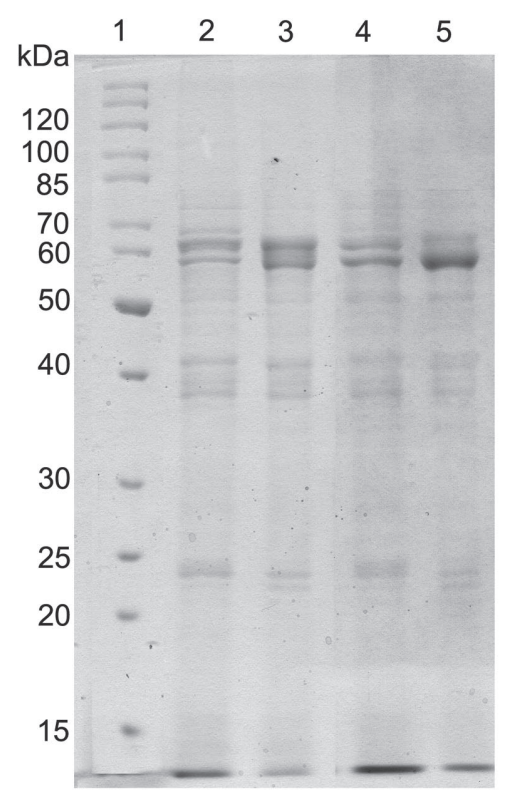

Fig. 2. SDS-PAGE of trypsin-activated B. thuringiensis protoxins from HD1 and BTA strain bioinsecticides, produced in 51 fermentors. Lanes: 1. Molecular mass, 2. BTA in medium A, 3. HD1 in medium A, 4. BTA in medium B, 5. HD1 in medium B

\section{DISCUSSION}

In this study, soybean or groundnut were used as nitrogen source, and starch or hull-less barley, as carbon source in ratios commonly used in most industrial scale productions of $B$. thuringiensis bioinsecticides. According to the results obtained this cultivar of barley could perfectly substitute starch in the soybean based media 
Table 4. Comparative costs for production of one kg of dry biomass by the HD1 strain using four different media

\begin{tabular}{|c|c|c|c|c|c|}
\hline \multirow{2}{*}{ Media } & \multirow{2}{*}{ Media components } & \multirow{2}{*}{$\begin{array}{l}\text { Quantity used in } \\
\text { media }\end{array}$} & \multirow{2}{*}{$\begin{array}{l}\text { Cost of quantity } \\
\text { used [US } \$]^{1}\end{array}$} & \multicolumn{2}{|c|}{$\begin{array}{l}\text { Total cost for production of } 1 \mathrm{~kg} \text { dry } \\
\text { biomass [US } \$ \text { ] }\end{array}$} \\
\hline & & & & shake flask & fermentor \\
\hline \multirow{3}{*}{ Medium A } & soybean & $12.8[\mathrm{~g} / \mathrm{l}]$ & 0.0151 & \multirow{3}{*}{6.53} & \multirow{3}{*}{9.80} \\
\hline & starch & $12.2[\mathrm{~g} / \mathrm{l}]$ & 0.0459 & & \\
\hline & salt solution & $0.315[\mathrm{ml} / \mathrm{l}]$ & 0.024 & & \\
\hline \multirow{3}{*}{ Medium B } & soybean & $12.8[\mathrm{~g} / \mathrm{l}]$ & 0.0151 & \multirow{3}{*}{3.86} & \multirow{3}{*}{4.43} \\
\hline & barley & $12.2[\mathrm{~g} / \mathrm{l}]$ & 0.0078 & & \\
\hline & salt solution & $0.315[\mathrm{ml} / \mathrm{l}]$ & 0.024 & & \\
\hline \multirow{3}{*}{ Medium C } & groundnut & $12.8[\mathrm{~g} / \mathrm{l}]$ & 0.0413 & \multirow{3}{*}{8.80} & \multirow{3}{*}{ NT } \\
\hline & starch & $12.2[\mathrm{~g} / \mathrm{l}]$ & 0.0459 & & \\
\hline & salt solution & $0.315[\mathrm{ml} / 1]$ & 0.024 & & \\
\hline \multirow{3}{*}{ Medium D } & groundnut & $12.8[\mathrm{~g} / \mathrm{l}]$ & 0.0413 & \multirow{3}{*}{5.67} & \multirow{3}{*}{ NT } \\
\hline & barley & $12.2[\mathrm{~g} / \mathrm{l}]$ & 0.0078 & & \\
\hline & salt solution & $0.315[\mathrm{ml} / \mathrm{l}]$ & 0.024 & & \\
\hline
\end{tabular}

${ }^{1}$ all prices were calculated according to the prices of Iran domestic market on August, 2008

NT - not tested

and the cost of media for producing one kg dry biomass would be lower by $28.3 \%$ and $57.8 \%$ during the production of BTA and HD1 bioinsectisides, respectively (Tables $2,4)$. Using the " $\mathrm{B}$ " medium BTA reached a maximum toxin production after cultivation for only $22 \mathrm{~h}$ (Fig. 1), but HD1 reached the same level after $30 \mathrm{~h}$. Using starch allows improvement of $B$. thuringiensis delta-endotoxin production mainly by the HD1 cultures (Ghribi et al. 2007). Such an improvement was of a great interest whilst calculating the cost of bioinsecticide production, and this study showed that interestingly, commercialgrade starch can be substituted by barley flour which has 57-63\% starch in its chemical composition (Grausgruber et al. 2004). Moreover, hull-less barley usually has a higher total protein content (12.5-15.9\%) than hulled barley and other cereals (Linko et al. 1989; Helm and Francisco 2004) and such proteins can be used as the second nitrogen source for the bulk production of $B$. thuringiensis The other medium (A), with a relatively more expensive ingredient (commercial-grade starch), requires a longer cultivation period especially during BTA production, and thus has higher overall production costs. The toxin production yield of $B$. thuringiensis strains produced in our proposed medium (the soybean-based medium B) was comparable to the levels obtained using other media. We concluded that the use of food barley in production of $B$. thuringiensis has many advantages. It is available nearly throughout the world with relatively competitive costs; permits faster sporulation, comparable biomass production, and shorter fermentation time and is also easy to prepare and to store. Such a medium composition can provide very useful substrates for production of the B. thuringiensis bioinsecticide, particularly in Iran and countries that have high levels of barley production.

\section{ACKNOWLEDGMENTS}

We thank Dr. J. F. Charles, Pasteur Institute, Paris, France for provision of reference strains also, Mr. H. Ghomi, technical staff at the Division of Microbial Industries, National Institute of Genetic Engineering and Biotechnology for his assistance during the course of this study. This research was partly supported by a grant from the Center of Excellence for Integrated Pest and Diseases Management of Oil Crops of Iran which is greatly appreciated.

\section{REFERENCES}

Bradford M.M. 1976. A rapid and sensitive method for the quantification of microgram quantities of protein utilizing the principle of protein-dye binding. Ann. Biochem. 72: 248-54.

Dregval O.A., Cherevach N.V., Andrienko O.E., Vinnikov A.I. 1999. The effect of a soil extract on the development of $\mathrm{Ba}$ cillus thuringiensis on its synthesis of an insecticidal endotoxin. Mikrobiol. Z. 61: 40-44.

Dregval O.A., Cherevach N.V., Vinnikov A.I. 2002. Influence of composition of the nutrient medium on growth and development of entomopathogenic bacteria Bacillus thuringiensis. Mikrobiol. Z. 64: 44-48.

Ghribi D., Zouari N., Trigui W., Jaoua S. 2007. Use of sea water as salts source in starch- and soya bean-based media, for the production of Bacillus thuringiensis bioinsecticides. Proc. Biochem. 42: 374-378.

Grando S., Macpherson H.G. 2008. Food barley: importance, uses and local knowledge. International Center for Agricultural Research in the Dry Areas. http://icarda. cgiar.org/ /Publications/Price_List/book3/food\%20barley.pdf

Grausgruber H., Scheiblauer J., Schönlechner R., Ruckenbauer P., Berghofer E. 2004. Variability in chemical composition and biologically active constituents of cereals. p. 23-26. In: “Genetic Variation for Plant Breeding". Proc. of 17th EUCARPIA General Cong. 8-11 September, Tulln, Austria. 
Helm C.V., Francisco A.D. 2004. Chemical characterization of Brazilian hulless barley varieties, flour fractionation, and protein concentration. Sci. Agric. 61: 593-597.

Jing-Wen Z., Ya-Fei Ch., Zheng-Hong X., Zi-Niu Y., Shou-Wen Ch. 2007. Production of thuringiensin by fed-batch culture of Bacillus thuringiensis subsp. darmstadiensis 032 with an improved $\mathrm{pH}$-control glucose fooding strategy. Proc. Biochem. 42: 52-56.

Kumar A., Sra K., Sangodkar U.M.X., Sharma V.P. 2000. Advances in the bio-control of mosquito vectors utilizing Bacillus sphaericus and Bacillus thuringiensis var. israelensis. Proc. Natl. Acad. Aci. India LXX: 1-20.

Laemmli U.K. 1970. Cleavage of structural proteins during the assembly of the head of bacteriophage T4. Nature 227: 680-685.

Linko R., Lapvetelainen A., Laakso P., Kallio H. 1989. Protein composition of a high-protein barley flour and barley grain. Cereal Chem. 66: 478-482.

Luna C.L., Silva G.R., Rios E.M. 2004. Bacillus thuringiensis var. israelensis production involving re-use of the supernatant. Biotechnol. Lett. 26:143-145.

Mummigatti S.G., Raghunathan A.N. 1990. Influence of media composition on the production of delta-endotoxin by Bacillus thuringiensis var. thuringiensis. J. Invertebr. Pathol. 55: 147-151.

Poopathi S., Kumar K.A. 2003. Novel fermentation media for production of Bacillus thuringiensis subsp. israelensis. J. Econ. Entomol. 96: 1039-1044.

Prabakaran G., Balaraman K. 2006. Development of a cost-effective medium for the large scale production of Bacillus thuringiensis var. israelensis. Biol. Control 36: 288-292.
Saalma H.S., Foda M.S., Dulmage H.T., Sharaby E.L. 1983. Novel fermentation medium for production of delta endotoxin from Bacillus thuringiensis. J. Invertebr. Pathol. 41: 8-19.

Zouari N., Bensikali S., Jaoua S. 2002. Production of delta-endotoxins by Bacillus thuringiensis strains exhibiting various insecticidal activities towards Lepidoptera and Diptera in gruel and fish meal media. Enzyme Microb. Technol. 31: 411-418.

\section{POLISH SUMMARY}

\section{OPRACOWANIE OPŁACALNEJ POŻYWKI DO PRODUKCJI BIOINSEKTYCYDU BACILLUS THURINGIENSIS PRZY UŻYCIU SPOŻYWCZEGO JĘCZMIENIA}

Porównywano zmieniony genetycznie jęczmień, Hordeum vulgare L. odmiana valfajr, ze skrobią handlowej klasy używanej jako źródło węgla oraz pożywki sojowe wykorzystywane do hodowli uzyskania zarodnikowania B. thuringiensis Berliner i do produkcji delta-endotoksyny.

Do badań użyto obiecujący, nowo izolowany szczep tej bakterii (BTA). Do pożywki w ilościach śladowych dodano następujące związki: $\mathrm{MgCl}_{2} \mathrm{CaCl}_{2}$ i $\mathrm{MnCl}_{2}$. Pożywki porównywano na wytrząsarce, a następnie przy użyciu sprzętu do fermentacji. Oceniana biomasa i wytwarzanie delta-endotoksyny, po zastąpieniu w pożywkach sojowych skrobii przez mąkę jęczmienna, nie różniły się istotnie. Stwierdzono natomiast różnice pomiędzy dwoma badanymi szczepami pod względem biomasy i produkcji toksyny. Porównanie kosztu przygotowania pożywek wykazało, że jęczmień spożywczy jest ekonomiczną alternatywą do produkcji bioinsektycydu BTA, w stosunku do skrobii handlowej jakości. 